INDEPENDENT JOURNAL OF MANAGEMENT \& PRODUCTION (IJM\&P)

http://www.ijmp.jor.br

v. 12, n. 5, July-August 2021

ISSN: 2236-269X

DOI: 10.14807/ijmp.v12i5.1390

\title{
RELATIONSHIP BETWEEN DEVELOPING MANAGER AND MANAGERIAL ECONOMICS: A THEORETICAL OVERVIEW
}

\author{
Md. Hasanur Rahman \\ Comilla University, Bangladesh \\ E-mail: hasanur.cou@gmail.com \\ Shapan Chandra Majumder \\ Comilla University, Bangladesh \\ E-mail: scmajumder_71@yahoo.com
}

Submission: $7 / 17 / 2020$

Revision: 9/1/2020

Accept: 9/23/2020

\section{ABSTRACT}

The purpose of this study was to identify the relationship between developing managers and managerial economics. This study examines the contributions of managerial economics to developing managers. Current study deals with a complete critical analysis of theoretical overview based on journals, books, and other sources. Managerial performance, skill, and effectiveness have been discussed in aspect of managerial economics. The bidirectional analysis proves that managerial performance creates economic efficiency and effectiveness. The major contributions of this analysis give the knowledge and way of developing a manager by supporting managerial economics. The stakeholder of this study can able to make a bridge between management and managerial economics.

Keywords: Manager; Economics; Management; Efficiency; Effectiveness 
DOI: $10.14807 /$ ijmp.v12i5.1390

\section{INTRODUCTION}

The concept of developing the manager is the process of owning the appropriate skills to manage the operations and function of an organization to achieve the occupational, institutional, and intimate objectives. This process involves many kinds of practical measures like the style of leadership operations, the improvement of employment quality and skills, as well as ethical and cultural improvement which support the concerned managers to achieve significant skills and behaviour.

The managerial concept in the economics field was firstly introduced by Adam Smith in the 18th century in his book An Inquiry into the Nature and Causes of the Wealth of Nations (Smith and Stewart, 1963). And a widespread of economic theory known as Leissez-faire theory which explains the importance of an active manager to the process of product generation by active production. The product innovation and quality of product assure by an effective manager (Berends et al. 2014). Managerial economics looks like a way of the procedure of interlink between managerial activities and economic production and distribution with effective planning and strategic effectiveness (Brickley et al. 2015).

According to Mansfield et al. (1999) the principal concern of managerial economics is in the field of cost minimization, cost analysis, decision rule principle, utilization of production time, and reduction principle of system loss in production which are also similar with (Petersen \& Lewis, 1997; Kaufman, 2010).

Those kinds of principles work as the theory of modern economics and corporate economics in the production field. The decision rule principle should be working as the seeding process of production. The efficiency of production and the effective distribution of commodities largely depend on the time principle (Aoki, 2006).

The concept of efficiency in economics or the economies scale of production demonstrates the cost minimization strategy which systematically depends on managerial strategy and performance (Jung \& Klein, 2005; Schmitt \& Sadowski, 2003). The manager can build up the chain between productions and make available distribution amount the different groups of the consumer.

Case analysis is discussed; here in the cases of the developing manager, we assume an individual that starts new work as a trainee hotel manager in Khulna city that is under new ownership. The owner has some problems with the existing staff members. In absence of a 
DOI: 10.14807/ijmp.v12i5.1390

housekeeping manager due to illness, the new manager needs to determine how he or she manages this kind of situation.

The scenario is that this hotel situated in central Khulna with consists of 30 rooms mainly double and 5 single rooms with lobby but no restaurant for breakfast. So the new manager in this organization might have the responsibility and objective to maintaining the circumstances.

The current study will compare various management styles applied by the organization for fostering the value and flow of services to run up the satisfaction level of employees, members, consumers, and owners. Moreover, it will discuss the leadership characteristics and examine the communication process for analysis of effectiveness in managerial operation. This study will also explains the motivation for achieving the agreed upon goals and objectives for the corporate world as well as evaluate the managerial decision process needed to support attainment of objectives and achieve economic efficiency.

The main objective is to analyse the relationship between developing manager and managerial economics in the aspect of production, distribution, and services.

Specific Objectives:

i. to demonstrate the principles and practice of management and managerial behaviour

ii. to identify the effectiveness of organizational management in economics overview

iii. to analyse the interrelation between managerial activities and the effectiveness of managerial economics

The next, section 2 discusses the literatures review; section 3 presents the methodology of this study. The principal and practice of management behaviour is discussed in section 4, while in section 5 the paper discusses review of the potential of a manager. Managerial ability and justification are presented in section 6, while section 7 is about carrier target and then the paper finally presents the conclusion in section 8 .

\section{LITERATURE REVIEW}

This study presents a brief literature review which is presented in Table 1. The main purpose of this section is evaluating the existed literature on managerial economics and management. 
INDEPENDENT JOURNAL OF MANAGEMENT \& PRODUCTION (IJM\&P)

http://www.ijmp.jor.br

v. 12, n. 5, July-August 2021

ISSN: 2236-269X

DOI: 10.14807/ijmp.v12i5.1390

Table 1: Brief of Literature Review

\begin{tabular}{|c|l|}
\hline Name of Author & \multicolumn{1}{|c|}{ Results/ Findings } \\
\hline Mailath (2004) & $\begin{array}{l}\text { Managerial skills depend on the size of a firm and business strategy. } \\
\text { Managerial skills also support to increase business activities. } \\
\text { Unidirectional relation between a manager and the firm's production } \\
\text { activity. }\end{array}$ \\
\hline Goldstein and Onyeiwu (2007) & Managerial economics fills the gap between economics and management. \\
\hline Sporleder (1992) & $\begin{array}{l}\text { Managerial economics support to make a marketing channel with superior } \\
\text { managerial performance and effectiveness. }\end{array}$ \\
\hline Harrigan (1983) & $\begin{array}{l}\text { A methodological change in business strategy helps to increase the } \\
\text { productions }\end{array}$ \\
\hline Sokoya (2000) & $\begin{array}{l}\text { Managerial performance accelerates the public sector productivity in } \\
\text { developing economies. }\end{array}$ \\
\hline Chen et al. (2010) & $\begin{array}{l}\text { Small and medium capital equity business largely depends on managerial } \\
\text { effectiveness. }\end{array}$ \\
\hline Isaga et al. (2015) & $\begin{array}{l}\text { The owner and manager interaction increase the production efficiency in } \\
\text { developing countries and Managerial activities work as puss factor of } \\
\text { development in SME and large business. }\end{array}$ \\
\hline Kacperczyk (2011) & $\begin{array}{l}\text { Managerial performance reduces the time volatility and also reduces the } \\
\text { system loss in production and distributions. }\end{array}$ \\
\hline Ghosh and Chowdhury (2008) & $\begin{array}{l}\text { Production, distribution, business strategy, and effectiveness largely } \\
\text { depends on firms or institutional manager }\end{array}$ \\
\hline
\end{tabular}

The current study works as a bridge between developing managers and managerial economics due to mitigate the literature gap. In the above literature and as per our sequential knowledge of other researchers, the subject areas of this study have never been conducted any study. This study analyzes the effective ways of developing managers in the aspect of managerial economics.

\section{METHODOLOGY}

Current study deals with a complete critical analysis of theoretical overview based on journals, books, and other sources. Secondary information has been used to create unique explanation and primary information's have assigned to explain the case study. Theoretical study also completed by (Gashenko et al., 2016; Michailova \& Liuhto, 2001; Scandura \& Williams, 2000).

\section{UNDERSTANDING THE PRINCIPLES AND PRACTICE OF MANAGEMENT BEHAVIOUR}

\subsection{Compare Different Management Style}

A manager can observe the institution, member, and consumer behavior to maintaining the systematic work for attaining efficiency. The management style characterises ways of making a decision and relating to a subordinate. The manager has to follow some style of maintaining the work procedure. Managerial leadership has some styles and mechanisms, like autocratic, democratic, and laissez-faire leadership styles (Sun \& Anderson, 2012; Sunindijo 
DOI: 10.14807/ijmp.v12i5.1390

et al., 2007; Cuny, 2002). There are three basic leadership styles that should be followed by the manager to organize the operations.

\subsubsection{Autocratic leadership}

The decision is the power which can be taken without consideration of others. The autocratic leadership style is one where the manager has the supreme legal power to take any kind of decision (De Cremer, 2006; Amanchukwu et al., 2015). Under the autocratic leadership style, the well-being of stakeholders is judged by the manager. There are no considerations of any skilled or experienced subordinates.

This system is not suitable and it is difficult to maintain the organization system towards production and distribution efficiency. There are two types of autocratic leadership here; firstly, a directive autocrat makes decisions unilaterally and micro-manages subordinates, where the subordinate means the members of the organization. Secondly, is a lenient autocrat who makes decisions unilaterally but gives subordinates latitude in carrying out this work.

\subsubsection{Democratic Leadership Style}

Democratic style is where the manager allows the staff and stakeholders to take part in decision-making, and all of the issues are agreed upon by the majority or best priority (Foels et al. 2000). The communication is extended in both directions from top to bottom and bottom to top and vice versa, which is a more effective system when decisions are taken from bottom to top.

This style can be predominantly useful and appropriate when a complex decision needs to be made that required a range of specialist skills. It is commonly said that democratic leadership is needed to operate a challenging situation and it enhances the efficiency of a manager to operate the overall system.

According to Choi, (2007), Ray and Ray (2012) there are some characteristics of democratic leadership that help managers as presented in the following:

i. The decision-making process involves a group of individuals, employees, executives, managers and owners.

ii. The governing body of management highly encourages the staff and members in management operations and productions like to work team members.

iii. It is the most effective managerial system in modern management operation (Harris \& Chapman, 2004). 
DOI: 10.14807/ijmp.v12i5.1390

iv. Democratic leadership style helps the employees to get promotion in their jobs and also encourages them towards getting concentration in the self-tasks.

The characteristics demonstrate that the democratic style is much effective for a new manager to manage the overall system of work procedure.

\subsubsection{Leissez-faire Leadership Style}

One of the oldest leadership styles is the Leissez-faire style where management takes a lifeline role in the productions of an institution to providing guidance for any need. The employees or staff are allowed to bring their own ideas and creativity accompaniments in their specific areas to expand the market size and quality standards.

The manager is looked upon as more of a mentor than a leader (Bush, 2008). This type of style is needed for a multinational company, joint corporations, heavy industry, etc. Leissezfaire leadership has few chances for the success of getting efficiency in managerial activities.

\subsection{Leadership Characteristics in the Organization}

The managerial style burnishes the overall system of organizations like production, maintenance of demand-supply chain, managerial skill, management behaviour, staff performance, and consumer satisfaction. It is necessary to mention that the most efficient management style is democratic leadership and sometimes this system known as the participatory leadership in the management process in the modern economics or business environment. Where the organization command top to bottom and bottom to top. The autocratic style is also needed in management behaviour to create a monopoly and solve the bureaucratic problem in business phenomena (Harms et al., 2018).

\subsection{Communication Processes in this Business}

Communication is the basic term that summarizes the sending and receiving of messages (Daft et al. 1987). The way employees communicate can explore or shout down a company. Think of the difference between criterion employs and the message to convey to the guest. A manager thinks that the organization wants to do business with people who can conduct the company philosophy to guest and gives outstanding services. Production, distribution, and consumption take place in the communication process which called the lifeblood of business.

To maintaining communication, some of the components like encoding, the medium of transmission, decoding, and feedback are important. Here needed to mention that a manager 
DOI: 10.14807/ijmp.v12i5.1390

should maintain the communication, control, operating, and organizing capability for attaining success (Townsend \& Gershon, 2020).

i. Email

In the current scenario, the most common useable method of communication is email. Organizations use this transmission to communicate managers, stuffs, and outfield to operating the official activity.

\section{ii. Meeting}

This is another method of communication in official and unofficial approach. A manager used this method to communicate with members and staff. This is the formal communication process that is more effective to get the real reaction of staff, members, and consumers.

\section{iii. Written}

Written as the traditional process of transferring the information and experiences with the staff and key members of the institution. It is also the formal way of communication in business, non-business, government, nongovernment, and chain of production activities. According to this approach, a manager can communicate including application, letter, notice, and letterhead to different levels of members and staff.

\section{iv. Mobile Phone and the World Wide Web}

In the modern economy and business, the greatest communication method is the mobile phone. Owners can operate and communicate with managers and managers to stuff finally stuff to the consumer. the mobile phone used to communicate all-time 24 hours that make the communications easier and more effective for each other to solve any kind of problem like as mismanagement, misbehave, less decoration and cleaning rooms by informing the hotel manager.

\subsection{Analyse the Organizational Culture and Strategic Change}

The manager should be set up an objective and activity plan in addition that, it is necessary to learn the principles and practice of managerial behaviour with respect to firms, stuff, and consumer behaviour or culture. Under this learning objective, the management style or management leadership also discussed. Observations of firms and consumer behaviour support game theory (Shapiro, 1998).

What should be best and effective, it depends on managerial actions with consideration of autocratic, democratic, and leissez-faire management style. The price setting, optimum production, distribution, and cost reduction are the vital strategic change of an organization. 
DOI: 10.14807/ijmp.v12i5.1390

The basic principle of strategic and organizational change for a manager is what should be produced? How to be produced? And for whom to be produced? those support the economics principle of initial problem analysis. Consumer and household analysis identify the needs to be producing to meet the necessities of society. Effective managers regulated to fill the gap between production and distributions (Erengüc et al. 1999).

\subsection{Strategic Change and Solution Strategy}

An effective manager has some characteristics to operate the institution within a systematic manner, rules, and regulations. The characteristics like creativity, positive attitude, cultural affinity, warmth and competence, empathy, accountability, honesty, and patience (Gupta, 1984). Based on those characters it is possible to find out a solution for attaining economic efficiency and the culture will be positively changed by the following achievement:

i. Eliminate the information gap \& provide legal information.

ii. $\quad$ Proper utilize manpower and resource.

iii. Manage and increase the single room

iv. Increase the decoration

v. Train up and be useful in new technology.

vi. Staff efficiency and time savings activity

vii. Create a new restaurant for breakfast

viii. Increase the communication skill, all of the individuals inside the hotel

ix. Advertisement and outdoor publicity. If the manager practices those actions against the problem, it is possible to overcome and earn benefits and profit as a business organization expected.

\section{BE ABLE TO REVIEW OWN POTENTIL?}

The current section considers that two several parts, first developed management and supervisory skill, and how to develop management skills for the manager? in order to get personal job security and institutional efficiency. The second one is the managerial strengths and weaknesses. The concern is how to overcome threats and weaknesses?

\subsection{Assessing Own Management Skills}


DOI: 10.14807/ijmp.v12i5.1390

According to the business dictionary, the managerial skill is the liability to make a business decision and lead inferiority within a company. There is some common expertise that is helping to get more efficiency than the previous time.

\subsubsection{Motivation}

In the concept of developing a manager, the first achievement is the ability to motivate staff, members, and co-coordinators (Buble, 2014). A manager who can motivate their employees is a true asset to their company. These types of interactions not only increasing staff productivity but also increase marginal productivity. Important skills in this area include the following object:

i. The employees are motivated to take ownership of an institution.

ii. Creating an energetic and environment-friendly workplace

iii. Supporting the co-workers means that the staff and member in this job

iv. Progressive award and incentive for outstanding performance.

\subsubsection{Problem-solving}

The problem-solving is the key factor of an idol manager. Three basic problems in the economics field like what to produce, how to produce, for whom to produce can be solved by an effective manger. That is the skill of set authority in managers to identify, face, and overcome the preceding problems that might arise in the workplace. In this context the learning matters are the following:

i. Identify the probable issues before they create any harms.

ii. Ability to face any kind of problem with meeting the current resources.

iii. Able to interpret calculating the problem statement.

\subsubsection{Communication}

Communication is known as business blood. The Responsibilities of the manager are to conducting efficiently in both current and retired employees who work under them and outfield of the institution. The manager should maintain some criteria for communication like as:

i. Maintain a chain of lines for communication with the co-worker.

ii. Negotiating to each other to maintain the efficiency of erotic capital.

iii. Managers can lead to effective meetings that are both fruitful and sensitive to time constraints.

\subsubsection{Technical Skills}


DOI: 10.14807/ijmp.v12i5.1390

Technical skills must be necessary for a manager and using mobile phones, tab, land phones, computers, and other technologies. Developing a sustainable career need to well known in technical skills. Technical skill helps to maintain a chain between producer and consumer. Modern business institutions have computerized their daily work in order to data collect, policymaking, growth and trend analysis, etc. Technical skill includes the following statement:

i. Technical support to make a bridge between firms and households.

ii. Providing information and data security to the stakeholder.

iii. Generating report and drafting, presentation and displaying

\subsection{Personal Strengths, Weaknesses, Opportunities, Threats (SWOT)}

SWOT analysis is an effective technique for evaluating the manager's strengths and weaknesses, and for the estimate, both the opportunities like a door opens to the manager. The threats manager face from opponent production or distribution authority.

\subsubsection{Personal strength}

To develop a manager, it's not only the task for oneself but also the task of a team which means all of the stuff, manager, and organizational owner. But the manager gets more liability to operate firms or production organizations. Development is teamwork, assume that a team to enhance production organizations.

The strength is the following:

i. The ability to care for customers, time consideration, and optimum resource utilization.

ii. The lead consultant has strong reputed in an inside production house.

iii. No need for higher managerial approval.

iv. Offer good services to the customer.

v. Be able to change direction quickly, as soon as possible.

\subsubsection{Weakness}

i. Lack of capital accumulation to support targeted products and services.

ii. The Limited amount of team members, staff, and outfield members.

iii. Personal tensed, pressure, mental illness, hot temper and miss communications

\subsubsection{Opportunities}


DOI: 10.14807/ijmp.v12i5.1390

i. The business sector will be expanding to multivariate production and services, with targeted production ability which supports economic theory and practices.

ii. Cooperate with government initiative, subsidy, regulation, the responsibility to encourage the local business and utilization of local resources.

iii. Greater technology and a better environment can ensure the extension of firm size.

\subsubsection{Threats}

A small change in the focus of a large competitor might wipe out any market position achieved by the intelligence of a manager (Dyson, 2004; Pickton \& Wright, 1998).

\subsection{SMART Objective and Targets to Develop Own Potential}

By using SMART objectives, managers can ensure both short-term and long-term focus and ensure success (Walravens \& Ballon, 2013). In the previous section where we discussed managerial skill and development in the aspect of productions and distributions now, we can summarize and practice within the SMART objective.

i. Specific- Target a Specific area for improvement for example, it increases the room facilities in a hotel with arguing of the current problem and enhances the consumer surplus it would be the specification.

ii. Measurable- quantify or qualify and suggest an indicator of a project.

iii. Assignable- identify who will do it likely to the manager.

iv. Realistic- state what result can realistically be achieved, given available resources, staff, members, and outfield co-operators.

v. Time Related- evaluate when the output can be achieved. So the SMART objective can helps to maintain a smooth decorum in a firm's products and services. This objective supports to get the effectiveness \& efficiency of a manager.

\section{THE ABILITY OF SHOWING MANAGERIAL SKILLS WITHIN A BUSINESS AND SERVICES CONTEXT}

According to this heading, the learning objective is leading and managing a team or accumulating a group leads to teamwork where managerial skill supports the operation, communication, control, and organizing ability (Lewis et al., 1982; Wong, 2009: Lewis et al., 1982; Wong, 2009). 
DOI: 10.14807/ijmp.v12i5.1390

Under the learning objective here assume a case study illustrated where the study isThere is a hotel in the Khulna city, Bangladesh. The hotel consists of 25 double rooms and five single rooms. There has a new owner and appointed a new trainee manager. The institution consists of some stuff like receptionist, housekeeper, cooker, and others.

According to the learning objective, the housekeeping is ill and the manager takes over the housekeeping department. So the overall scenario is like that, the manager cannot find any documentation. The manager has to plan for the day from scratch which means to continue. This situation sometimes called a critical situation. As a managerial aspect, it's called weakness within strengths, weaknesses, opportunities, threats SWOT theories.

\subsection{Lead and Motive a Team to Achieve an Agreed Goal and Objective; Based on Case Study.}

According to senior managers, these situations have to have a challenge for a new hotel manager. The new manager can be overcome this situation by doing a systematic work procedure. The first work is to set up a team and operate this team carefully. The necessary steps to overcome this situation in absence of a housekeeper.

\subsubsection{Supervise Housekeeping/Store House}

In absence of housekeeping manager, the hotel manager should supervise the room and ensure the hotel standard by utilizing the dynamic team. Housekeeping duty includes cleaning and turning down rooms, re-record rooms, and guest level and carry out the room services.

\subsubsection{Monitor Supplies}

Hotel managers see that hotel guests have enough supplies both within hotel rooms and in the public areas that team visits, such as the spa and washrooms. The manager's intelligence ensures a constant supply of the supplies needed.

\subsubsection{Investigate Complaints}

As a housekeeping manager receive and act on complaints from hotel guests relating to their consumer needs in hotel rooms or public areas. A consumer should complain if their room was not properly decorated, clean, and castrate properly or complain that the physical facilities like a bathroom.

\subsubsection{Identify}


DOI: 10.14807/ijmp.v12i5.1390

The team or group task to identify the housekeeping problem, collect information to find out the way like as search a new housekeeper or manager can operate based on his/ her personal managerial skill.

\subsubsection{Allocate}

To allocate the duty for successive operation. The leader can allocate the task of room management and others to different groups of individuals in the absence of a housekeeper manager.

\subsubsection{Communications}

The manager is susceptible to manage the aggregate situation in the case of housekeeping illness which creates managerial weakness. It's possible to trounce by communicating with each other like stuff and consumer.

\subsubsection{Motivation}

One of the managerial skills where the manager able to motivate team \& team members to keep patience and maintaining well-behaved for all of the customers. If the manager and stuff play democratic managerial leadership it's possible to achieve institutional goals and efficiency in the short-run and long-run period.

\subsection{Justify the Managerial Decision made to Support the Achievement of Agreed Goal and Objective}

In this section, the current study considers the key term justifiability of managerial decision, the common factor needs to be a consideration.

i. Quality and communication: that means the measure of the process to build up relations with the customer.

ii. Leader information: helps to provide legal information.

iii. Goal Congruence: focused on decision making or the right choice of decision.

iv. SWOT analysis: that helps the manager of new innovation and gathers new experiences which co-operate in the future.

v. Time Management: Time management is an approach of time allocations with achieving reliable managerial aimed at increasing efficiency in production, an increase in firm size, labor, and technical efficiency. The time factor helps to manage the operation based on consumer demand. 
DOI: $10.14807 /$ ijmp.v12i5.1390

\section{IDENTIFY CAREER TARGETS AND PRODUCE A HOLISTIC DEVELOPMENT PLAN IN MANAGERIAL ECONOMICS}

Identify the career targets and holistic development plan in managerial economics was examined by (Lindsay et al., 2007; Resnik \& Harmon, 1983). In this section the main objective of how to gather managerial skill, personal skill, and support to career development. We need to know the meaning of career development.

According to Herr (1992) career development is the long-term progression of managing the employee's work expertise within or between production organizations. On the other hand, another definition is career development is to achieve the goal of learning, leisure, work, and transitions in order to come up to a personally determined and amplify preferred upcoming future in a production and service organization.

\subsection{Explain how to Own Managerial and Personal Skill will Support Career Development:}

At the beginning of measure the career development

i. It is necessary to know how to managerial and personal skill relates to career development. The improvement of skill is the way of developing a person and his or her skill sets to add value for the economic active organization. Nurturing an attitude of affluence for permanent learning is the key to success in the workplace. Then successfully in quest of the cocoon of training or on-the-job opportunities to developing career.

ii. Explain what is the strategy for career development and how to personal and managerial skill helps to achieve that strategic objective. The Practical Strategies for Career Development is describing bellow:

a) Have realistic expectations: career development takes time and effort. Moreover, it might be responsible to anticipate promotion with time considerations. The improvement of staff life largely depends on institutional or business trends. A positive trend makes beneficiaries of all stakeholders. When a company thinking big, the timescales of internal members should be a moderately extensive bracket, efficient skills help to get promotion as soon as possible.

b) Determining goal: our goal should focal point on the step to step in the path, but we should always keep the by and large strategy in mind. 
DOI: 10.14807/ijmp.v12i5.1390

c) Decide attainable action: that means to take valuable action for achieving something with consideration of personal cost.

\subsection{Review Career and Personal Development Needs: Current Performance and Future Needs to Produce a Development Plan}

The Career starting of a manager in production and service organization it is necessary to review personal progress and organizational progress. The carrier plan should be changed with respect to new owners and the new authority that is why review helps to identify the strength and weaknesses (Jackson \& Sirianni, 2009). The role of the manager is to deliver a constant positive brand experience to the customer every day. Positive action can make a positive change in the carrier. Hard work can belong unsociable hours at times but the rewards in job satisfaction and building a motivated team working together are worth it.

\section{CONCLUSION}

The summary of the current study considered that developing a manager is a major task for individuals and organizations who want to plan, realize, and control the operations of an organization. All managers have their own leadership style but most similar traits to succeed. The strategic change like pricing, costing, production, distribution, invention, and innovation largely depends on managerial intelligence (Rumelt et al., 1991; Boeker, 1997).

Managerial economics also supports firms' behaves of operation involved in the modern economy (Moss, 1985; Lambertini, 2000; Fershtman, 1985; Augier \& Teece, 2009). The developing manager should effective in the short term and long term leadership techniques and employment generation which are vital part of the economics field.

The current study provides a substantial way of interlink between developing managers and managerial economics. This study collaborates the individuals and organizations to increase managerial skills and effectiveness with supporting the economic theory and practices.

\section{REFERENCES}

Amanchukwu, R. N., Stanley, G. J., \& Ololube, N. P. (2015). A review of leadership theories, principles and styles and their relevance to educational management. Management, 5(1), 614.

Aoki, I. (2006). Min-Max principle of entropy production with time in aquatic communities. Ecological Complexity, 3(1), 56-63.

Augier, M., \& Teece, D. J., (2009). Dynamic capabilities and the role of managers in business strategy and economic performance. Organization science, 20(2), 410-421.

Berends, H., Jelinek, M., Reymen, I., \& Stultiëns, R. (2014). Product innovation processes in small firms: Combining entrepreneurial effectuation and managerial causation. Journal of 
INDEPENDENT JOURNAL OF MANAGEMENT \& PRODUCTION (IJM\&P)

http://www.ijmp.jor.br

v. 12, n. 5, July-August 2021

ISSN: 2236-269X

DOI: 10.14807/ijmp.v12i5.1390

\section{Product Innovation Management, 31(3), 616-635.}

Boeker, W. (1997). Strategic change: The influence of managerial characteristics and organizational growth. Academy of management journal, 40(1), 152-170.

Brickley, J., Smith, C., \& Zimmerman, J. (2015). Managerial economics and organizational architecture. McGraw-Hill Education.

Buble, M., Juras, A., \& Matić, I. (2014). The relationship between managers' leadership styles and motivation. Management: journal of contemporary management issues, 19(1), 161-193.

Bush, T. (2008). From management to leadership: semantic or meaningful change?. Educational management administration \& leadership, 36(2), 271-288.

Chen, C., Comerton-Forde, C., Gallagher, D. R., \& Walter, T. S. (2010). Investment manager skills in small-cap equities. Australian Journal of Management, 35(1), 23-49.

Choi, S. (2007). Democratic leadership: The lessons of exemplary models for democratic governance. International journal of leadership studies, 2(3), 243-262.

Cuny, F. C. (2000). Principles of disaster management lesson 7: management leadership styles and methods. Prehospital and disaster medicine, 15(1), 78-86.

Daft, R. L., Lengel, R. H., \& Trevino, L. K. (1987). Message equivocality, media selection, and manager performance: Implications for information systems. MIS quarterly, 355-366.

De Cremer, D. (2006). Affective and motivational consequences of leader self-sacrifice: The moderating effect of autocratic leadership. The Leadership Quarterly, 17(1), 79-93.

Dyson, R. G. (2004). Strategic development and SWOT analysis at the University of Warwick. European journal of operational research, 152(3), 631-640.

Erengüç, Ş. S., Simpson, N. C., \& Vakharia, A. J. (1999). Integrated production/distribution planning in supply chains: An invited review. European journal of operational research, 115(2), 219-236.

Fershtman, C., (1985). Managerial incentives as a strategic variable in duopolistic environment. International Journal of Industrial Organization, 3(2), 245-253.

Foels, R., Driskell, J. E., Mullen, B., \& Salas, E. (2000). The effects of democratic leadership on group member satisfaction: An integration. Small-Group Research, 31(6), 676-701.

Gammelgaard, B., \& Larson, P. D., (2001). Logistics skills and competencies for supply chain management. Journal of Business logistics, 22(2), 27-50.

Ghosh, P., \& Chowdhury, P. R. (2008). Managerial economics. McGraw-Hill Education.

Goldstein, D., \& Onyeiwu, S. (2004). Toward a Liberal Arts Managerial Economics

Pedagogy. Available at SSRN 637103.

Gupta, A. K. (1984). Contingency linkages between strategy and general manager characteristics: A conceptual examination. Academy of Management Review, 9(3), 399412.

Harms, P. D., Wood, D., Landay, K., Lester, P. B., \& Lester, G. V. (2018). Autocratic leaders and authoritarian followers revisited: A review and agenda for the future. The Leadership Quarterly, 29(1), 105-122.

Harrigan, K. R. (1983). Research methodologies for contingency approaches to business strategy. Academy of Management Review, 8(3), 398-405. 
Harris, A., \& Chapman, C. (2004). Democratic leadership for school improvement in challenging contexts. Democratic Learning: The challenge to school effectiveness, 6(9), 164178.

Herr, E. L. (1992). Emerging trends in carrer counselling. International Journal for the Advancement of Counselling, 15(4), 255-288.

Jackson Jr, D. W., \& Sirianni, N. J. (2009). Building the bottom line by developing the frontline: Career development for service employees. Business Horizons, 52(3), 279-287.

Jung, H., \& Klein, C. M. (2005). Optimal inventory policies for an economic order quantity model with decreasing cost functions. European Journal of Operational Research, 165(1), 108-126.

Kacperczyk, M., Nieuwerburgh, S. V., \& Veldkamp, L. (2014). Time-varying fund manager skill. The Journal of Finance, 69(4), 1455-1484.

Kaufman, B. E. (2010). The theoretical foundation of industrial relations and its implications for labor economics and human resource management. ILR Review, 64(1), 74-108

Lambertini, L., (2000). Extended games played by managerial firms. The Japanese Economic Review, 51(2), 274-283.

Lewis, B. N., \& Pask, G. O. R. .O. N. (1982). The Development of Communication Skills, under Adaptively Controlled Conditions. Programmed Learning and Educational Technology, 19(2), 85-98.

Lindsay, C., McQuaid, R., \& Dutton, M. (2007). New approaches to employability in the UK: Combining'human capital development'and'Work First'strategies?. Journal of social policy, 36(4), 539-560.

Mailath, G. J., Nocke, V., \& Postlewaite, A. (2004). A business strategy, human capital, and managerial incentives. Journal of Economics \& Management Strategy, 13(4), 617-633.

Mansfield, E., Allen, W. B., Doherty, N. A., \& Weigelt, K. (1999). Managerial economics: Theory, applications, and cases (No. 338.5024658 M287 1999). New York: WW Norton.

Michailova, S., \& Liuhto, K. (2001). Organization and management research in transition economies: towards improved research methodologies. Journal of East-West

Business, 6(3), 7-46.

Moss, S. (1984). The History of the Theory of the Firm from Marshall to Robinson and Chamberlin: the Source of Positivism in Economics. Economica, 51(203), 307-318.

Pickton, D. W., \& Wright, S. (1998). What's swot in strategic analysis?. Strategic change, $7(2)$, p. 101-109.

Petersen, H. C., \& Lewis, W. C. (1997). Managerial economics. Pearson.

Ray, S., \& Ray, I. A. (2012). Understanding democratic leadership: some key issues and perception with reference to india's freedom movement. Afro Asian Journal of Social Sciences, 3(3.1), 1-26.

Resnik, A. J., \& Harmon, R. R. (1983). Consumer complaints and managerial response: A holistic approach. Journal of Marketing, 47(1), 86-97.

Rumelt, R. P., Schendel, D., \& Teece, D. J. (1991). Strategic management and economics. Strategic management journal, 12(S2), 5-29.

Samuelson, W. F., \& Marks, S. G. (2008). Managerial economics. John Wiley \& Sons. 
Schmitt, M., \& Sadowski, D. (2003). A cost-minimization approach to the international transfer of HRM/IR practices: Anglo-Saxon multinationals in the Federal Republic of Germany. International Journal of Human Resource Management, 14(3), 409-430.

Scandura, T. A., \& Williams, E. A. (2000). Research methodology in management: Current practices, trends, and implications for future research. Academy of Management journal, 43(6), 1248-1264.

Shapiro, C. (1989). The theory of business strategy. The Rand journal of economics, 20(1), 125-137.

Smith, A., \& Stewart, D. (1963). An Inquiry into the Nature and Causes of the Wealth of Nations (Vol. 1). Homewood, Ill: Irwin.

Sokoya, S. K. (2000). Personal predictors of job satisfaction for the public sector manager: Implications for management practice and development in a developing economy. Journal of business in developing nations, 4(1), 4.

Sunindijo, R. Y., Hadikusumo, B. H., \& Ogunlana, S. (2007). Emotional intelligence and leadership styles in construction project management. Journal of management in engineering, 23(4), 166-170.

Sun, P. Y., \& Anderson, M. H. (2012). The combined influence of top and middle management leadership styles on absorptive capacity. Management learning, 43(1), 25-51.

Taylor, M., \& Campbell, C. (1999). Communication skills in the operating department. British Journal of Theatre Nursing (United Kingdom), 9(5), 217-221.

Townsend, R., \& Gershon, M. (2020). Attaining Successful Construction Project Execution Through Personnel and Communication. Journal of Construction Engineering and Management, 146(9), 04020101.

V Gashenko, I. V., Vokina, S. G., Romanov, D. G., Bezrukova, T. L., \& Kozenko, Y. A. (2016). Theoretical and methodological aspects of innovation development in modern economic systems. Contemporary economics, 10(4), 363-372.

Walravens, N., \& Ballon, P. (2013). Platform business models for smart cities: from control and value to governance and public value. IEEE Communications Magazine, 51(6), 72-79.

Wong, W. N. Z. (2009). The strategic skills of business continuity managers: putting business continuity management into corporate long-term planning. Journal of Business Continuity \& Emergency Planning, 4(1), 62-68. 